\title{
Papers
}

\section{National cross sectional survey to determine whether the decision to delivery interval is critical in emergency caesarean section}

\author{
Jane Thomas, Shantini Paranjothy, David James
}

\begin{abstract}
Objective To examine the association between decision to delivery interval and maternal and baby outcomes.

Design National cross sectional survey.

Setting Maternity units in England and Wales.

Subjects reviewed 17780 singleton births (99\% of all births) delivered by emergency caesarean section in England and Wales between 1 May 2000 and 31 July 2000.

Main outcome measures Association between decision to delivery interval and baby outcomes (Apgar scores of $<7$ and $<4$ at five minutes and stillbirth) and maternal outcomes (requirement for special care additional to routine care after caesarean section and where care was provided).

Results Compared with babies delivered within 15 minutes, there was no difference in maternal or baby outcome for decision to delivery interval between 16 and 75 minutes. After 75 minutes, however, there was a significantly higher odds of a five minute Apgar score of $<7$ (odds ratio 1.7, 95\% confidence interval 1.2 to 2.4 ), and $50 \%$ increase in odds of special care additional to routine care for mothers.

Conclusion A decision to delivery interval of 30 minutes is not an absolute threshold for influencing baby outcome. Decision to delivery intervals of more than 75 minutes are associated with poorer maternal and baby outcomes and should be avoided.
\end{abstract}

\section{Introduction}

In the United Kingdom, the Department of Health has allocated $£ 1.5 \mathrm{bn}(\$ 2.7 \mathrm{bn} ; € 2.3 \mathrm{bn})$ to cover obstetric litigation over the next five years. ${ }^{1}$ Many cases involve possible intrapartum antecedents of cerebral palsy. To help improve intrapartum fetal care the National Institute for Clinical Excellence clinical guideline on electronic fetal monitoring recommends that "in cases of suspected or confirmed acute fetal compromise, delivery should be accomplished as soon as possible, accounting for the severity of the fetal heart rate abnormality and relevant maternal factors. The accepted standard has been that, ideally this should be accomplished within 30 minutes." ${ }^{2}$ The ability of hospitals to meet this standard was assessed in the national sentinel caesarean section audit. ${ }^{3}$

A systematic review found limited research to underpin this standard, and 30 minutes is an arbitrary threshold. ${ }^{2-7}$ It has been suggested that rapid delivery may be dangerous in itself for the fetus. However, the most compromised babies are most predisposed to a poorer outcome and are also often delivered with the least delay, and this needs to be taken into account when assessing the effects of a rapid delivery. ${ }^{8}$ Rapid delivery may also increase the risk of maternal mortality, as a result of surgery or factors such as general anaesthesia. ${ }^{10}$

Perceived urgency can be critical in motivating a caesarean section. A grading system for urgency was evaluated in the national sentinel caesarean section audit. ${ }^{3}$ Using data from this audit, we examined the association between decision to delivery interval and baby and maternal outcomes, after adjustment for clinical factors associated with poor fetal, neonatal, or maternal outcome.

\section{Methods}

The national sentinel caesarean section audit was designed to accurately measure caesarean rates and to assess the quality of care given to women having caesarean sections in England and Wales. ${ }^{3}$ Data were collected at the time of delivery. The dataset includes 99\% of all births between 1 May 2000 and 31 July 2000.

The decision to delivery interval for emergency caesarean is defined as the interval in minutes from the date and time of decision to carry out the caesarean section to the date and time of delivery of the baby. For our analysis, we categorised the data into 15 minute intervals $(0-15,16-30,31-45,46-60,61-75$, and $>75)$.

The perceived urgency for emergency caesarean was ascertained from asking which of the following statements most accurately describes "urgency" of the caesarean section: immediate threat to the life of the woman or fetus (grade 1); maternal or fetal compromise not immediately life threatening (grade 2); no maternal or fetal compromise but early delivery needed (grade 3); and delivery timed to suit the woman and staff (grade 4).

All contributory indications for caesarean were reported, and the most important (primary) indication was specified. The relation between these two variables has been evaluated and reported elsewhere. ${ }^{3}$

\section{Outcome measures}

The fetal outcomes were Apgar scores of $<7$ and $<4$ at five minutes and stillbirth; in these data, antepartum and intrapartum fetal deaths were not distinguished. It is, however, uncommon in the United Kingdom to perform a caesarean for an antenatal fetal death. To ensure exclusion of any antenatal fetal deaths, we examined the clinical data on all stillbirths. We excluded from further analysis one case where it was not clear that the baby was thought to be alive at the time of surgery.

The maternal outcomes were requirement for special care after caesarean section that was additional to routine postoperative care and where this care was provided. 
Table 1 Grade of urgency for all emergency caesarean sections and decision to delivery interval (minutes). Values are numbers (percentages) of women

\begin{tabular}{|c|c|c|c|c|c|}
\hline \multirow[b]{2}{*}{$\begin{array}{l}\text { Decision to delivery } \\
\text { interval (min) }\end{array}$} & \multicolumn{5}{|c|}{ Grade of urgency } \\
\hline & $\begin{array}{l}\text { Grade 1: Immediate threat to } \\
\text { life of woman or fetus } \\
(n=4622)\end{array}$ & $\begin{array}{l}\text { Grade 2: Maternal or fetal } \\
\text { compromise not immediately } \\
\text { life threatening }(n=9122)\end{array}$ & $\begin{array}{l}\text { Grade 3: No maternal or fetal } \\
\text { compromise but needs early } \\
\text { delivery ( } n=3689)\end{array}$ & Missing data ( $\mathrm{n=347)}$ & $\begin{array}{l}\text { All emergency caesarean } \\
\text { sections }(n=17780)\end{array}$ \\
\hline$\leq 15$ & $739(16.0)$ & $478 \quad(5.2)$ & $136 \quad(3.7)$ & $28 \quad(8.1)$ & $1381 \quad(7.8)$ \\
\hline $16-30$ & $1398(30.2)$ & $944(10.3)$ & $194 \quad(5.3)$ & $41(11.8)$ & 2577 (14.5) \\
\hline $31-45$ & 1057 (22.9) & $1906(20.9)$ & $576(15.6)$ & $50(14.4)$ & 3589 (20.2) \\
\hline $46-60$ & $496(10.7)$ & $1900(20.8)$ & 793 (21.5) & $72(20.7)$ & 3261 (18.3) \\
\hline $61-75$ & $214 \quad(4.6)$ & $1059(11.6)$ & $552(15.0)$ & $40(11.5)$ & $1865(10.5)$ \\
\hline Missing data & $203(4.4)$ & $849 \quad(9.3)$ & 133 (3.6) & $31 \quad(8.9)$ & $1216 \quad(6.8)$ \\
\hline
\end{tabular}

\section{Statistical analyses}

Data were analysed with Stata version 7.0. Our analysis was restricted to singletons delivered by emergency caesarean. Multiple pregnancies were excluded, as perinatal morbidity is known to be higher in this group and the babies cannot be treated independently.

We used separate logistic regression models to investigate the relation between decision to delivery interval and each outcome, adjusting for clinical factors known to be associated with poor baby outcome (for example, indication for caesarean section, grade of urgency, cardiotocography findings, type of anaesthesia) and maternal outcome (for example, body mass index, age, parity, ethnicity, previous caesarean section, use of antibiotic and acid prophylaxis). We obtained robust standard errors to account for the clustering of women within the 216 consultant led maternity units. ${ }^{11}$ A forward stepwise approach was adopted for inclusion of variables into the model; a $\mathrm{P}$ value $<0.05$ was used as the cut-off point for significance.

\section{Results}

Between 1 May 2000 and 31 July 2000, 17780 singletons were delivered by emergency caesarean in England and Wales. Perceived urgency was classified as grade 1 for $26.0 \%(n=4622)$, grade 2 for $51.3 \%(n=9122)$, and grade 3 for $20.8 \%(n=3689)$. Seven per cent of the women were delivered within 15 minutes and $22 \%$ within 30 minutes. Overall, $46 \%(\mathrm{n}=2137)$ of women with grade 1 urgency, $16 \%(n=1422)$ with grade 2 , and $9 \%$ $(\mathrm{n}=330)$ with grade 3 were delivered within 30 minutes (table 1$)$.

The most common primary indications for emergency caesarean were presumed fetal compromise, intrauterine growth retardation or an abnormal cardiogram (35\%), and failure to progress $(32 \%)$. Presumed fetal compromise was the primary indication for most $(66 \%)$ cases with grade 1 urgency (table 2).

Of the babies born by emergency caesarean, 3.4\% $(n=586)$ had a five minute Apgar score of $<7$ and 1.0\% $(\mathrm{n}=175)$ had a five minute Apgar score of $<4$. The stillbirth rate was 3.0 per 1000 singletons delivered by emergency caesarean section $(\mathrm{n}=53)$. Of these, most $(\mathrm{n}=43)$ were reported to be grade 1 urgency, six were grade 2 urgency, and three were grade 3 urgency. Grade of urgency was not known for one baby; the primary indication for caesarean was presumed fetal compromise.

Of the women who had an emergency caesarean $13 \%$ $(\mathrm{n}=2283)$ needed special care. Of these, $0.43 \%(\mathrm{n}=80)$ were admitted to an intensive care unit. Women who were delivered with short $(<30$ minutes) or long $(>75$ minutes) decision to delivery intervals were more likely to require special care (table 3).

Unadjusted odds ratios showed that babies delivered within 15 minutes had poorer outcomes compared with babies delivered after 30 minutes (table 3 ).
Compared with babies delivered within 15 minutes, the adjusted odds ratio for five minute Apgar scores of $<7$ were not significantly different for babies delivered between 16 and 75 minutes. Babies delivered after 75 minutes, however, had significantly higher odds of five minute Apgar scores of $<7$ (odds ratio $1.7,95 \%$ confidence interval 1.2 to 2.4 ). Similar trends were seen for five minute Apgar scores of $<4$ (75 minutes 1.4, 0.7 to 2.5) and stillbirth (75 minutes $1.8,0.7$ to 4.2 ), but this did not reach statistical significance These odds ratios were adjusted for primary indication for caesarean, intrapartum fetal monitoring, grade of urgency, and type of anaesthesia (table 3).

We repeated this analysis with cases delivered within $30 \mathrm{~min}-$ utes as the reference group. We found no significant difference in the odds of a poor outcome for babies delivered in less than 30 minutes compared with those delivered between 31 and 75 minutes $(1.1,0.9$ to 1.4 for five minute Apgar score of $<7$ ). Babies delivered after 75 minutes, however, had an $80 \%$ increased odds of a five minute Apgar score of $<7$ (1.8, 1.3 to 2.4). Similar nonsignificant trends were seen for five minute Apgar scores of $<4$ and stillbirths.

Women who were delivered after 75 minutes had a 50\% increase in adjusted odds of requiring special care after delivery compared with women delivered within 15 minutes (1.5, 1.2 to 1.8). We found no difference between the odds of this outcome between a delivery interval of 15 minutes and intervals up to 75 minutes (table 3 ).

Women who were delivered after 75 minutes had a $60 \%$ increase in odds of requirement for special care compared with women delivered within 30 minutes (1.6, 1.4 to 1.9). We found no difference in maternal outcome in women delivered between 31 and 75 minutes (1.1, 0.9 to 1.2$)$.

\section{Discussion}

Prolonged decision to delivery intervals for emergency caesarean of more than 75 minutes may result in poor maternal and baby outcomes. Monitoring decision to delivery intervals remains important in evaluating quality of maternity care, and a reference time frame is needed. The generally accepted standard in the United Kingdom and elsewhere is 30 minutes. ${ }^{2}{ }^{12}$ Using data from the national sentinel caesarean section audit, we evaluated whether this time threshold is critical. ${ }^{3}$

Evidence to underpin the 30 minute standard is limited. We identified only five studies that address decision to delivery intervals for caesarean section and its effect on outcome. ${ }^{2467}$ Of these, three were included in a previous review. ${ }^{2}$ Since that review, two further studies have been published. ${ }^{813}$ These, however, were based on the same data, and only one is considered here. ${ }^{8}$ Of the remaining four studies, three were retrospective case note reviews of 296 emergency caesareans and the fourth was a prospective study of 533 emergency 
Table 2 Grade of urgency for all emergency caesarean sections and primary indication for caesarean section ( $\mathrm{n}=17 \mathrm{780})$. Values are numbers (percentages) of women

\begin{tabular}{|c|c|c|c|c|c|}
\hline \multirow[b]{2}{*}{$\begin{array}{l}\text { Primary indication for } \\
\text { caesarean section }\end{array}$} & \multicolumn{5}{|c|}{ Grade of urgency } \\
\hline & $\begin{array}{l}\text { Immediate threat to life of } \\
\text { woman or fetus }(n=4622)\end{array}$ & $\begin{array}{l}\text { Maternal or fetal compromise } \\
\text { not immediately life } \\
\text { threatening }(\mathrm{n}=9122)\end{array}$ & $\begin{array}{l}\text { No maternal or fetal } \\
\text { compromise but early } \\
\text { delivery needed ( } \mathrm{n}=3689 \text { ) }\end{array}$ & Missing data ( $\mathrm{n=347)}$ & $\begin{array}{l}\text { All emergency caesarean } \\
\text { sections }(n=17780)\end{array}$ \\
\hline \multicolumn{6}{|l|}{ Fetal } \\
\hline Failure to progress & $330(7.1)$ & $3471(38.0)$ & $1848(50.1)$ & $123(35.4)$ & $5772(32.5)$ \\
\hline Breech presentation & $50(1.1)$ & $360 \quad(3.9)$ & $676(18.3)$ & $34 \quad(9.8)$ & $1120(6.3)$ \\
\hline Malpresentation or unstable lie & $80(1.7)$ & $302(3.3)$ & $154(4.2)$ & $11(3.2)$ & $547 \quad(3.1)$ \\
\hline $\begin{array}{l}\text { Presumed fetal compromise, } \\
\text { intrauterine growth } \\
\text { retardation, or abnormal } \\
\text { cardiotocogram } \\
\end{array}$ & $3047(65.9)$ & $3097(33.9)$ & $23(0.6)$ & $87(25.1)$ & $6254(35.2)$ \\
\hline Cord prolapse & $137(3.0)$ & $4 \quad(0.0)$ & 0 & $1 \quad(0.3)$ & $142(0.8)$ \\
\hline Chorioamnionitis & $14 \quad(0.3)$ & $46 \quad(0.5)$ & $7 \quad(0.2)$ & $1(0.3)$ & $68 \quad(0.4)$ \\
\hline Other & $115(2.5)$ & $219(2.4)$ & $61 \quad(1.6)$ & $9 \quad(2.6)$ & $404 \quad(2.3)$ \\
\hline \multicolumn{6}{|l|}{ Maternal } \\
\hline \multicolumn{6}{|l|}{ Placenta praevia } \\
\hline Actively bleeding & $117(2.5)$ & $107(1.2)$ & $24 \quad(0.6)$ & $6(1.7)$ & $254(1.4)$ \\
\hline Not actively bleeding & $50(1.1)$ & $118(1.3)$ & $23 \quad(0.6)$ & $6(1.7)$ & $197(1.1)$ \\
\hline $\begin{array}{l}\text { Antepartum or intrapartum } \\
\text { haemorrhage }\end{array}$ & $132(2.9)$ & $108 \quad(1.2)$ & $27 \quad(0.7)$ & $\begin{array}{ll}1 & (0.3)\end{array}$ & 268 (1.5) \\
\hline Placental abruption & $217(4.7)$ & $52(0.6)$ & $3 \quad(0.1)$ & $4 \quad(1.1)$ & $276(1.5)$ \\
\hline $\begin{array}{l}\text { Pre-eclampsia, eclampsia, or } \\
\text { HELLP }\end{array}$ & $203 \quad(4.4)$ & $350 \quad(3.8)$ & $26 \quad(0.7)$ & $\begin{array}{ll}3 & (0.9)\end{array}$ & 582 (3.3) \\
\hline Maternal medical disease & $31 \quad(0.7)$ & $157(1.7)$ & $52(1.4)$ & $3 \quad(0.9)$ & $243(1.4)$ \\
\hline Previous caesarean section & $22(0.5)$ & $156(1.7)$ & $322(8.7)$ & 11 (3.2) & $511 \quad(2.9)$ \\
\hline Uterine rupture & $31 \quad(0.7)$ & $11 \quad(0.1)$ & $\begin{array}{ll}4 & (0.1) \\
\end{array}$ & 0 & $46 \quad(0.3)$ \\
\hline Maternal request & $11 \quad(0.2)$ & $86 \quad(0.9)$ & $206 \quad(5.6)$ & $7 \quad(2.0)$ & $310(1.7)$ \\
\hline $\begin{array}{l}\text { Previous poor obstetric } \\
\text { outcome }\end{array}$ & $2(0.0)$ & $15 \quad(0.2)$ & $15(0.4)$ & $1 \quad(0.3)$ & $33(0.2)$ \\
\hline $\begin{array}{l}\text { Previous physically or } \\
\text { emotionally traumatic vaginal } \\
\text { delivery }\end{array}$ & $3 \quad(0.1)$ & $17 \quad(0.2)$ & $31 \quad(0.8)$ & $\begin{array}{ll}3 & (0.9)\end{array}$ & $54 \quad(0.3)$ \\
\hline Previous infertility & 0 & $2(0.0)$ & $2(0.0)$ & 0 & $4 \quad(0.0)$ \\
\hline Other & $23 \quad(0.5)$ & $155(1.7)$ & $81 \quad(2.2)$ & $6(1.7)$ & $265(1.5)$ \\
\hline Missing data & $7 \quad(0.1)$ & $289(3.2)$ & $104(2.8)$ & $30 \quad(8.6)$ & $430 \quad(2.4)$ \\
\hline
\end{tabular}

HELLP=haemolysis, elevated liver enzymes, and low platelet count syndrome.

caesareans. $^{4-8}$ These studies reported either no difference or reduced morbidity with longer decision to delivery intervals. No adjustments were made for confounding factors. Three studies reported admission to neonatal intensive care unit, a non-specific measure of neonatal morbidity. Again there were inconsistent findings; one study showed increasing rates of admission to the neonatal intensive care unit with longer decision to delivery interval ${ }^{7}$; the other two studies detected no difference. ${ }^{4}$ Only one study reported maternal morbidity measures in relation to decision to delivery intervals in a retrospective review of 75 women who had emergency caesareans. ${ }^{4}$ No difference was detected in outcomes between those delivered in less than 30 minutes or more.

This study is the largest to address the issue of decision to delivery intervals and outcomes. The data include comprehensive ascertainment of all caesarean sections from all maternity units in England and Wales over a three month period. The clinical information and details of timing (decision and procedures) were obtained prospectively. The limitations of the data are the relatively restricted measures of fetal and maternal outcomes. Ideally the most valid immediate measures of fetal or neonatal hypoxia are five minute Apgar scores, acid base balance, and neonatal encephalopathy. ${ }^{2}$ Only five minute Apgar scores were collected in the national sentinel caesarean section audit. Five minute Apgar scores of $<4$ are associated with long term neurodevelopmental sequelae, including cerebral palsy. ${ }^{14}$ Five minute Apgar scores of $<7$ are a marker for metabolic aci- dosis, but are less clear for long term outcome. ${ }^{2}$ The maternal outcome of requirement for special care additional to routine postoperative care is a non-specific marker of maternal morbidity, which is influenced by other factors such as comorbidities.

Our findings are consistent with previous studies. ${ }^{4-8}$ In univariate analysis shorter decision to delivery intervals are associated with poorer baby outcomes. After adjusting for other clinical factors, however, decision to delivery intervals of less than 30 minutes did not improve or worsen the maternal or baby outcomes. Outcomes do not change for decision to delivery intervals of up to 75 minutes. For all emergency caesareans, however, delays in delivery of more than 75 minutes are associated with poorer maternal and baby outcomes; this effect is greater when maternal or fetal compromise is suspected-that is, grade 1 or grade 2 urgency.

General anaesthesia for emergency caesareans can contribute to poorer baby and maternal outcomes and regional anaesthesia is generally recommended..$^{15-19}$

Maternity services need to ensure that they can respond rapidly to obstetric emergencies and expedite delivery within a limited time frame. Monitoring decision to delivery intervals remains important in evaluating quality of maternity care and a reference time frame is needed. In many situations, trying to achieve delivery within 30 minutes may be unnecessary. Our study is the first to show that prolonged decision to delivery intervals of more than 75 minutes may result in poor maternal and baby outcomes. Even though our data suggest that 75 min- 
Table 3 Association between decision to delivery interval, clinical factors, five minute Apgar scores of $<7$ and $<4$, stillbirth, and maternal requirement for special care

\begin{tabular}{|c|c|c|c|c|c|c|c|c|c|c|c|c|}
\hline \multirow[b]{2}{*}{ Variable } & \multicolumn{3}{|c|}{5 minute Apgar score $<7$} & \multicolumn{3}{|c|}{5 minute Apgar score $<4$} & \multicolumn{3}{|c|}{ Stillbirth } & \multicolumn{3}{|c|}{$\begin{array}{l}\text { Maternal requirement for special } \\
\text { care }\end{array}$} \\
\hline & № (\%) & $\begin{array}{l}\text { Unadjusted } \\
\text { odds ratio } \\
(95 \% \text { CI) }\end{array}$ & $\begin{array}{c}\text { Adjusted } \\
\text { odds ratio* } \\
(95 \% \mathrm{Cl})\end{array}$ & № (\%) & $\begin{array}{l}\text { Unadjusted } \\
\text { odds ratio* } \\
(95 \% \mathrm{Cl})\end{array}$ & $\begin{array}{l}\text { Adjusted } \\
\text { odds ratio } \\
\text { (95\% Cl) }\end{array}$ & No $(\%)$ & $\begin{array}{l}\text { Unadjusted } \\
\text { odds ratio } \\
\text { (95\% CI) }\end{array}$ & $\begin{array}{c}\text { Adjusted } \\
\text { odds ratio* } \\
\text { (95\% CI) }\end{array}$ & No (\%) & $\begin{array}{l}\text { Unadjusted } \\
\text { odds ratio } \\
(95 \% \mathrm{Cl})\end{array}$ & $\begin{array}{c}\text { Adjusted } \\
\text { odds ratio* } \\
\text { (95\% Cl) }\end{array}$ \\
\hline \multicolumn{13}{|l|}{$\begin{array}{l}\text { Decision to } \\
\text { delivery } \\
\text { (min): }\end{array}$} \\
\hline$\leq 15$ & $87(6.5)$ & 1 & 1 & $32(2.4)$ & 1 & 1 & $11(0.8)$ & 1 & 1 & $\begin{array}{l}194 \\
(14.1)\end{array}$ & 1 & 1 \\
\hline $16-30$ & $139(5.5)$ & $\begin{array}{l}0.8 \\
(0.6 \text { to } 1.1)\end{array}$ & $\begin{array}{l}0.9 \\
\text { (0.6 to } 1.2)\end{array}$ & $44(1.7)$ & $\begin{array}{l}0.7 \\
\text { (0.5 to 1.1) }\end{array}$ & $\begin{array}{l}0.8 \\
(0.5 \text { to } 1.3)\end{array}$ & $16(0.6)$ & $\begin{array}{l}0.8 \\
(0.3 \text { to } 1.7)\end{array}$ & $\begin{array}{l}0.8 \\
\text { (0.3 to 1.7) }\end{array}$ & $\begin{array}{l}301 \\
(11.7)\end{array}$ & $\begin{array}{l}0.8 \\
(0.6 \text { to 1.0) }\end{array}$ & $\begin{array}{l}0.8 \\
\text { (0.7 to 1.1) }\end{array}$ \\
\hline $31-45$ & $106(3.0)$ & $\begin{array}{l}0.4 \\
(0.3 \text { to } 0.6)\end{array}$ & $\begin{array}{l}1.0 \\
\text { (0.7 to } 1.4)\end{array}$ & $25(0.7)$ & $\begin{array}{l}0.3 \\
(0.2 \text { to } 0.5)\end{array}$ & $\begin{array}{l}0.7 \\
(0.4 \text { to } 1.3)\end{array}$ & $5(0.1)$ & $\begin{array}{l}0.2 \\
(0.1 \text { to } 0.5)\end{array}$ & $\begin{array}{l}0.4 \\
(0.1 \text { to } 1.3)\end{array}$ & $\begin{array}{l}361 \\
(10.1)\end{array}$ & $\begin{array}{l}0.7 \\
(0.6 \text { to } 0.8)\end{array}$ & $\begin{array}{l}0.9 \\
(0.8 \text { to } 1.2)\end{array}$ \\
\hline $46-60$ & $71(2.2)$ & $\begin{array}{l}0.3 \\
(0.2 \text { to } 0.4)\end{array}$ & $\begin{array}{l}1.1 \\
\text { (0.8 to } 1.7)\end{array}$ & $23(0.7)$ & $\begin{array}{l}0.3 \\
(0.2 \text { to } 0.5)\end{array}$ & $\begin{array}{l}1.3 \\
(0.7 \text { to } 2.3)\end{array}$ & $3(0.1)$ & $\begin{array}{l}0.1 \\
(0.0 \text { to } 0.4)\end{array}$ & $\begin{array}{l}0.5 \\
(0.1 \text { to } 1.9)\end{array}$ & $277 \quad(8.5)$ & $\begin{array}{l}0.6 \\
(0.5 \text { to } 0.7)\end{array}$ & $\begin{array}{l}0.9 \\
(0.7 \text { to } 1.1)\end{array}$ \\
\hline $61-75$ & $35(1.9)$ & $\begin{array}{l}0.3 \\
(0.2 \text { to } 0.4)\end{array}$ & $\begin{array}{l}1.1 \\
\text { (0.7 to } 1.7)\end{array}$ & $10(0.5)$ & $\begin{array}{l}0.2 \\
(0.1 \text { to } 0.5)\end{array}$ & $\begin{array}{l}1.0 \\
(0.4 \text { to } 2.3)\end{array}$ & $4(0.2)$ & $\begin{array}{l}0.3 \\
(0.1 \text { to } 0.8)\end{array}$ & $\begin{array}{l}1.6 \\
(0.5 \text { to } 5.3)\end{array}$ & $\begin{array}{l}197 \\
(10.6)\end{array}$ & $\begin{array}{l}0.7 \\
(0.6 \text { to } 0.9)\end{array}$ & $\begin{array}{l}1.1 \\
(0.8 \text { to } 1.4)\end{array}$ \\
\hline$>75$ & 116 (3.1) & $\begin{array}{l}0.4 \\
(0.3 \text { to } 0.6)\end{array}$ & $\begin{array}{l}1.7 \\
(1.2 \text { to } 2.4)\end{array}$ & $31(0.8)$ & $\begin{array}{l}0.3 \\
(0.2 \text { to } 0.5)\end{array}$ & $\begin{array}{l}1.4 \\
(0.7 \text { to } 2.5)\end{array}$ & $11(0.3)$ & $\begin{array}{l}0.3 \\
(0.1 \text { to } 0.7)\end{array}$ & $\begin{array}{l}1.8 \\
(0.7 \text { to } 4.2)\end{array}$ & $\begin{array}{l}752 \\
(19.4)\end{array}$ & $\begin{array}{l}1.5 \\
(1.2 \text { to } 1.7)\end{array}$ & $\begin{array}{l}1.5 \\
(1.2 \text { to } 1.8)\end{array}$ \\
\hline \multicolumn{13}{|l|}{$\begin{array}{l}\text { Grade of } \\
\text { urgency: }\end{array}$} \\
\hline $\begin{array}{l}\text { Need early } \\
\text { delivery }\end{array}$ & $31(0.9)$ & 1 & 1 & $11(0.3)$ & 1 & 1 & $3(0.1)$ & 1 & 1 & $233 \quad(6.3)$ & 1 & 1 \\
\hline $\begin{array}{l}\text { Urgent, not } \\
\text { life } \\
\text { threatening }\end{array}$ & $189(2.1)$ & $\begin{array}{l}2.5 \\
(1.7 \text { to } 3.6)\end{array}$ & $\begin{array}{l}1.7 \\
\text { (1.1 to 2.6) }\end{array}$ & $46(0.5)$ & $\begin{array}{l}1.7 \\
(0.8 \text { to } 3.6)\end{array}$ & $\begin{array}{l}0.8 \\
(0.4 \text { to } 1.9)\end{array}$ & $6(0.1)$ & $\begin{array}{l}0.8 \\
(0.2 \text { to } 3.3)\end{array}$ & $\begin{array}{l}0.9 \\
(0.2 \text { to } 3.1)\end{array}$ & $\begin{array}{l}1154 \\
(12.7)\end{array}$ & $\begin{array}{l}2.1 \\
\text { (1.8 to } 2.5)\end{array}$ & $\begin{array}{l}1.6 \\
(1.3 \text { to } 1.9)\end{array}$ \\
\hline $\begin{array}{l}\text { Urgent, life } \\
\text { threatening }\end{array}$ & $352(7.9)$ & $\begin{array}{l}9.8 \\
(6.8 \text { to } 14.1)\end{array}$ & $\begin{array}{l}2.9 \\
(1.8 \text { to } 4.8)\end{array}$ & $115(2.6)$ & $\begin{array}{l}8.6 \\
(4.3 \text { to } 17.0)\end{array}$ & $\begin{array}{l}1.6 \\
(0.6 \text { to } 4.0)\end{array}$ & $43(0.9)$ & $\begin{array}{l}11.5 \\
(3.6 \text { to } 36.8)\end{array}$ & $\begin{array}{l}8.3 \\
(1.5 \text { to } 44.7)\end{array}$ & $\begin{array}{l}857 \\
(18.6)\end{array}$ & $\begin{array}{l}3.4 \\
(2.8 \text { to } 4.0)\end{array}$ & $\begin{array}{l}2.2 \\
(1.7 \text { to } 2.7)\end{array}$ \\
\hline
\end{tabular}

${ }^{*}$ Adjusted for primary indication for caesarean section, cardicotography findings, grade of urgency, and type of anaesthesia.

utes rather than 30 minutes is the clinically significant threshold, adopting 75 minutes could lead to complacency. In our opinion, the 30 minute decision to delivery interval should remain as the benchmark for service provision for caesarean sections of grade 1 and grade 2 urgency. In addition, the 75 minute decision to delivery interval should be added as a clinically important audit standard, and all emergency caesarean deliveries should occur within this time.

We thank those involved with data collection for the national sentinel caesarean section audit and the audit working group. A full list of contributors has been published in the audit report.

Contributors: JT conceived and designed the study; she will act as guarantor for the paper. SP carried out data analysis, interpreted the results, and

\section{What is already known on this topic}

Decision to delivery interval for emergency caesarean section within 30 minutes is the international standard for fetal compromise

A systematic review suggests that evidence supporting this standard is weak

Short decision to delivery intervals have been associated with poorer baby outcomes and may harm the mother

\section{What this study adds}

A decision to delivery interval of 30 minutes is not an absolute threshold for influencing baby outcome

Intervals of more than 75 minutes are associated with poorer maternal and baby outcomes

Decision to delivery interval remains an important measure of quality of maternity care drafted the paper with JT and DJ. The guarantor accepts full responsibility for the conduct of the study, had access to the data, and controlled the decision to publish.

Funding: The national sentinel caesarean section audit received funding from the Department of Health, the National Institute for Clinical Excellence, and the Department of Health Northern Ireland. The National Collaborating Centre for Women's Health and Children's Health is funded by the National Institute for Clinical Excellence.

Competing interests: None declared.

Ethical approval: Ethical approval was sought but was not required for phase 1 of the national sentinel caesarean section audit.

1 Eddy JW. Is childbirth safe in the UK and are there enough obstetricians? Letter to a chief executive. Hosp Med 2000;61:204-6.

2 Royal College of Obstetricians and Gynaecologists. The use of electronic fetal monitoring: the use and interpretation of cardiotocography in intrapartum fetal monitoring. No 8. London: RCOG Press, 2001.

3 Thomas J, Paranjothy S, and Royal College of Obstetricians and Gynaecologists: Clinical Effectiveness Support Unit. The national sentinel caesarean section audit report. London: RCOG Press; 2001.

4 Schauberger CW, Rooney BL, Beguin EA, Schaper AM, Spindler J. Evaluating the thirty minute interval in emergency cesarean sections. J Am Coll Surg 1994;179:151-5.

5 Roemer VM, Heger-Romermann G. [Emergency cesarean section-basic data]. Zeitschrift Geburtshilfe Perinatol 1992;196:95-9. [In German.]

6 Chauhan SP, Roach H, Naef RW, Magann EF, Morrison JC, Martin JN Jr. Cesarean section for suspected fetal distress. Does the decision-incision time make a difference? $J$ Reprod Med 1997:49.347-59.

7 Dunphy BC, Robinson JN, Sheil OM, Nicholls JSD, Gillmer MDG. Caesarean section for fetal distress, the interval from decision to delivery, and the relative risk of poor neonatal condition. J Obstet Gynaecol 1991;11:241-4.

8 MacKenzie IZ, Cooke I. Prospective 12 month study of 30 minute decision to delivery intervals for "emergency" caesarean section. BMJ 2001;322:1334-5.

9 James D. Caesarean section for fetal distress. BMJ 2001:322:1316-7.

10 Confidential Enquiries into Maternal Deaths. Why mothers die 1997-1999: the fifth report of the Confidential Enquiries into Maternal Deaths in the United Kingdom. No 5. London: RCOG Press, 2001.

11 Zeger SL and Liang KY. Longitudinal data analysis for discrete and continuous outcomes. Biometrics 1986;42:121-30.

12 American College of Obstetricians and Gynecologists technical bulletin. Fetal heart rate patterns: monitoring, interpretation, and management. No 207, Jul 1995 (replaces No 132, Sept 1989). Int J Gymaecol Obstet 1995:51:65-74.

13 MacKenzie IZ, Cooke I. What is a reasonable time from decision-to-delivery by caesarean section? Evidence from 415 deliveries. Br J Obstet Gynaecol 2002;109:498-504.

14 Goodwin TM, Belai I, Hernandez P, Durand M, Paul RH. Asphyxial complications in the term newborn with severe umbilical acidemia. Am J Obstet Gynaecol 1002;167:150612.

15 Lertakyamanee J, Chinachoti T, Tritrakarn T, Muangkasem J, Somboonnanonda A, Kolatat T. Comparison of general and regional anesthesia for cesarean section: success 
rate, blood loss and satisfaction from a randomized trial. J Med Assoc Thai 1999;82:672-9.

16 Kolatat T, Lertakyamanee J, Tritrakarn T, Somboonnanonda A, Chinachot T, Muangkasem J. Effects of general and regional anesthesia on the neonate (a prospective, randomized trial). J Med Assoc Thai 1999;82:40-5.

17 Dick W, Traub E, Kraus H, Tollner U, Burghard R, Muck J. General anaesthesia versus epidural anaesthesia for primary caesarean section-a comparative study. Eur J Anaesthesiol 1992;9:15-21.

18 Wallace DH, Leveno KJ, Cunningham FG, Giesecke AH, Shearer VE, Sidawi JE. Randomized comparison of general and regional anesthesia for cesarean delivery in pregnancies complicated by severe preeclampsia. Obstet Gynecol 1995;86:193-9.

19 Hong J-Y, Jee Y-S, Yoon H-J, Kim SM. Comparison of general and epidural anesthesia in elective cesarean section for placenta previa totalis: maternal hemodynamics, blood loss and neonatal outcome. Int J Obstet Anesth 2003;12:12-6. doi $10.1136 /$ bmj.38031.775845.7C

National Collaborating Centre for Women's and Children's Health, London NW1 4RG

Jane Thomas director

Shantini Paranjothy research fellow

School of Human Development, Queen's Medical Centre, Nottingham NG7 2UH

David James professor of fetomaternal medicine

Correspondence to:J Thomas JThomas@rcog.org.uk 